\title{
«ГОСУДАРСТВОПОНИМАНИЕ»
}

\author{
А. В. Зырянов \\ Южно-Уральский государственный университет, г. Челябинск
}

\begin{abstract}
В настоящей статье предпринята попытка теоретического обоснования категории «государствопонимание» в качестве системообразующего элемента теории государства, места приложения сил, связанных с онтологическими, гносеологическими, методологическими и типологическими изысканиями. Дано понятие государствопонимания, установлены его типы, соответствующие парадигмам научной рациональности, раскрыта их содержательная основа, проведен ретроспективный анализ концептуальных воззрений отдельных ученых и философов на природу государства, определен предполагаемый вектор развития государствоведения.

Ключевые слова: государствопонимание, государство, парадигма, тип, субъект, объект, рефлексия.
\end{abstract}

Анализ состояния современной цивилизации позволяет сделать вывод о наличии тотальной проблемы, связанной с актуализацией, оптимизацией, формализацией, унификацией и функционализацией идеи государственности, которая уже несколько тысяч лет выступает базовым организационным инструментом развития человечества.

Многообразные формы государственных образований, изобретенные или приобретенные различными национально-культурными сообществами с целью обеспечения собственной жизнеспособности, самодостаточности и/или исключительности, равным образом сталкиваются с вызовами наполненного кризисными процессами глобализирующегося мира, заставляющими включать механизмы эволюционной и коэволюционной адаптации.

Так, перед современной юридической наукой стоит масштабная задача, связанная с поиском эффективных средств познания и понимания сущностных оснований все усложняющихся и ускоряющихся процессов общественно-государственного уровня, созданием универсальной доктрины, обеспечивающей прогнозируемость и управляемость данных процессов.

В связи с этим представляется важным выработать адекватный специфике исторического времени ориентир научного познания для теории государства, ее усилить путем создания, введения в качестве предмета исследования такой категории, как «государствопонимание», призванной стать системообра- зующим элементом государствоведения, местом приложения сил, связанных с онтологическими, гносеологическими, методологическими и типологическими изысканиями.

Понятие государствопонимания хотелось бы определить следующим образом. Государствопонимание - это определяемая типом научной рациональности, сложившаяся в юридической и политической теории совокупность концептуальных взглядов на сущность государства, причины и пути его возникновения и развития, форму организации, устройства и функционирования государственной власти, роль в жизни общества, связь с правом.

Важно отметить, что проблема государствопонимания неразрывно связана с вопросом собственно понятия государства, который, являясь краеугольным камнем юридической науки, открыт и актуален по сей день. Сложность данного вопроса, поливариантность его решения в различные исторические эпохи отдельными мыслителями обусловлены сложностью познания и описания феноменов публичной, политической и государственной власти, которые, выступая организационными явлениями социальной действительности, носят многомерный и динамичный характер.

Вместе с тем научное исследование, понимание, определение понятия государства сопряжены, с массой негативных факторов объективного и субъективного свойства: включенность субъекта в объект познания, методологическая недостаточность, культур- 
ная изолированность, социальный заказ, политическая и экономическая конъюнктура, политическая ангажированность, идеологическая зависимость и др.

Принимая во внимание научное наследие и тысячелетний исторический опыт, посредством идеи государствопонимания мы попытаемся фундаментализировать теорию государства, установить принципы и вектор ее развития во взаимосвязи с природой эволюционных трансформаций системных отношений государства и общества, выявляя тем самым ориентиры и возможности современной юридической науки.

Далее обратим внимание на содержательную основу государствопонимания в виде специальной типологии, призванной определить классификацию отдельных типов государствопонимания в качестве смысловых моделей познания государства, включающих теоретическую конструкцию, предмет и метод соответствующих концепций.

Предваряя дальнейшую характеристику указанных типов, важно сказать о ее осуществлении в тесной взаимосвязи с типологией парадигм научной рациональности, отражающих исходную концептуальную схему, модель постановки проблем и их решения, методов исследования, господствующих в течение определенного исторического периода в научном сообществе.

Итак, предполагается, что можно выделить следующие научные типы государствопонимания:

1) антропоцентристско-механистический;

2) позитивистско-исторический;

3) системологически-альтернативистский.

Наименования указанных типов отражают совокупное представление о научных подходах к анализу статико-динамической сущности государства.

Далее, рассмотрим содержательную основу каждого из них.

1. Антропоцентристско-механистический.

Характерные особенности:

1) период генезиса - XVI - середина XIX вв.;

2) сопутствующая цивилизационная тенденция - от аграрного к индустриальному обществу;

3) определяющий тип научной рациональности - классический:

a) рефлексия научного знания - объект (или человек или общество или государство); б) объект познания - рационально устроенный, механически упорядоченный и линейно развивающийся согласно действующим в нем причинно-следственным закономерностям; отдельное явление, простая статичная система, существующая «сама по себе», представляющая собой механическую совокупность образующих ее элементов;

в) субъект познания - элиминируется в силу природной равнозначности; носитель чистого абстрактного знания, дистанцированный от объекта познания;

г) метод понимания - онтологический.

4) соответствующие политико-правовые концепции:

а) Н. Макиавелли - государство - политическое состояние общества; определяемая циничными отношениями властвующих и подвластных организация;

б) Ж. Боден - государство - осуществляемое верховной (суверенной - неделимой) властью управление множеством собственников, домохозяйств и их общим достоянием;

в) Г. Гроций - государство - определяемый социальной природой человека, совершенный союз свободных людей заключенный ради соблюдения права и общей пользы;

г) Т. Гоббс - государство - искусственно созданный равноправными людьми, путем самоограничения собственной свободы для обеспечения мира и благополучия, механизм, обладающий абсолютным суверенитетом;

д) Дж. Локк - государство - совокупность людей, в целях обеспечения свободы, равноправия и защиты собственности, учредивших форму коллективности, наделенную правом издавать законы и обеспечивать их исполнение посредством специальных органов во имя всеобщего блага;

е) Ш. Монтескье - государство - призванная обеспечить режим законности организация управления (продукт исторического развития общества), характеризующаяся порядком формирования и уровнем функциональной самостоятельности органов власти, обладающая специфической формой правления в силу качества «духа» того или иного народа предопределенного географическими факторами;

ж) Ж.-Ж. Руссо - государство - созданный волеустановлением народа, являющимся первоисточником и носителем суверенной власти, политический организм, призванный обеспечить гражданские права и свободы; 
3) Т. Пейн - государство - создаваемая на основе общественного договора организация с утверждаемой народом, обладающим верховной властью, формой правления;

и) И. Кант - государство - договорное, подчиняемое правовым законам объединение людей (индивидуальных субъектов нравственного сознания), призванное обеспечить гражданские свободы путем согласования конституции с принципами права («категорическим императивом»);

к) Гегель - государство - наивысшая самоцель состояния индивида, средство властной гармонизации гражданского общества (обеспечения свободы, безопасности, собственности), функционирующее в режиме законности идейно-политическое национальное единство.

2. Позитивистско-исторический.

Характерные особенности:

1) период генезиса - 2-я половина XIX середина XX вв.;

2) сопутствующая цивилизационная тенденция - от индустриального к постиндустриальному обществу;

3) определяющий тип научной рациональности - неклассический:

a) рефлексия научного знания - средства - объект;

б) объект познания - относителен научноисследовательской деятельности (виду научного описания), изменчив, зависим от условий существования, вовлечен в сеть взаимосвязанных событий; комплекс явлений, элемент мира сложных саморегулирующихся систем;

в) субъект познания - включен в объект познания, вовлечен в процесс получения знаний в качестве экспериментатора и интерпретатора;

г) метод понимания - гносеологический.

4) соответствующие политико-правовые концепции:

a) О. Конт - государство - общественная кооперация наделенных функциональными правами и обязанностями людей и социальных групп, необходимая для достижения общей цели, обладающая политической властью, качество которой эволюционирует (прогрессирует) во времени посредством нравственного и экономического совершенствования общественных отношений;

б) Г. Еллинек - государство - нормативное соотношение воль властвующих и подвластных, основанное на психологической допустимости властного господства, признании правомерности функционально удовлетворяющей власти;

в) Г. Спенсер - государство - продукт эволюции общественного организма, детерминированный его взаимодействием с окружающей средой, исторически претерпевающий функционально обусловленные трансформации;

г) К. Маркс - государство - основанная на экономической структуре общества (не зависящих от воли людей производственных отношениях, которым соответствуют формы общественного сознания) форма организации политической власти экономически господствующего класса, исторически эволюционирующая, способная реагировать на кризис базисных отношений революционными изменениями.

3. Системологически-альтернативистский.

Характерные особенности:

1) период генезиса - 2-я половина $\mathrm{XX}$ начало XXI вв.;

2) сопутствующая цивилизационная тенденция - от постиндустриального к информационному обществу;

3) определяющий тип научной рациональности - постнеклассический:

a) рефлексия научного знания - субъект средства - объект;

б) объект познания - относителен субъективной (ценностно-волевой) особенности понимания, открытая, сложная, нелинейная, самоорганизующаяся система; междисциплинарен, представляет единую системную картину реальности;

в) субъект познания - неделим с объектом познания, условие эволюции научного знания, условие антропного принципа, носитель социального целеполагания;

г) метод понимания - методологический;

4) соответствующие политико-правовые концепции:

a) государство - негэнтропийное явление социальной действительности, система самоорганизационных отношений, направленная на обеспечение жизнеспособности и целеполагаемого развития неравновесной общественной среды, характеризующаяся нелинейной (альтернативной) эволюционной динамикой своей функциональной структуры и формы, обусловленной внешними и внутренними параметрами порядка, которые взаимосвязаны с волевыми установками индивидов и их 
групп посредством субъектно-объектной рефлексии сознания (формулировка понятия государства основана на разрабатываемой автором синергетической концепции государствопонимания).

Подводя итог всему вышеизложенному, еще раз подчеркнем важность оформления и развития теоретического базиса государствоведения, в том числе путем обращения внимания юридической науки на категорию государствопонимания, способную стать благодатной основой для выработки адекватного реалиям современной цивилизации подхода к месту и роли государства в жизни человека и общества, подхода к принципам его развития (соразвития (саморазвития)) и функционирования с дальнейшим выходом на уровень стратегических рекомендаций относительно практики политико-правовой оптимизации.
Как показал проведенный анализ, теория государства претерпевает определенную стагнацию, связанную с кризисом методологической (мировоззренческой) адаптации к современному уровню научной рациональности, который в свою очередь, требуя фундаментального переосмысления классических догматических установок, предоставляя массу возможностей творческой реализации, способен стать ориентиром для определения эвристической ценности научных изысканий.

Вместе с тем представляется, что обозначенная проблема, свидетельствуя об открытости поля деятельности, станет привлекательным, а в перспективе возможно приоритетным, местом приложения сил юридического научного сообщества. Сам факт написания данной статьи является неким тому подтверждением.

Зырянов Алексей Викторович - кандидат юридических наук, преподаватель кафедры теории и истории государства и права, Южно-Уральский государственный университет, г. Челябинск. E-mail: Lotos495@mail.ru.

Статья поступила в редакцию 30 мая 2016 2.

DOI: 10.14529/law160302

\section{STATE INSIGHT}

\section{A. V. Zyrianov South Ural State University, Chelyabinsk, Russian Federation}

This article attempts to make a theoretical justification of the category of "state insight" as a backbone element of the theory of state, the points of application associated with the ontological, epistemological, methodological and typological research. The concept of state insight is given, its types appropriate to the paradigms of scientific rationality are recognized, and their substantial basis is revealed, a retrospective analysis of conceptual views of individual scientists and philosophers about the nature of the state is conducted, supposed vector of the development of constitutional law is defined.

Keywords: state insight, state, paradigm, type, subject, object, reflection. 
Aleksey Viktorovich Zyrianov - Candidate of Sciences (Law), associate professor, Department of Theory and History of State and Law, South Ural State University, Chelyabinsk, Russian Federation. E-mail: Lotos495@mail.ru.

Received 30 May 2016.

\section{ОБРАЗЕЦ ЦИТИРОВАНИЯ}

Зырянов, А. В. «Государствопонимание» / А. В. Зырянов // Вестник ЮУрГУ. Серия «Право». 2016. - T. 16, № 3. - C. 12-16. DOI: $10.14529 /$ law 160302.

\section{FOR CITATION}

Ziryanov A. V. "State insight". Bulletin of the South Ural State University. Ser. Law, 2016, vol. 16, no. 3, pp. 12-16. (in Russ.) DOI: 10.14529/law160302. 